\title{
Crystal Structure of a Lantern-Type Dirhodium(II) Complex with a cis-(2:2) Arrangement of Two Formamidinato and Two Trifluoroacetato Bridges
}

\author{
Makoto HANDA, ${ }^{* \dagger}$ Kazuki TAKAHASHI,* Asami Inoue,* Takahisa IKEUE, $*$ \\ Daisuke YoshiokA, ${ }^{* *}$ and Masahiro MiKurIYA**† \\ *Department of Chemistry, Interdisciplinary Graduate School of Science and Engineering, Shimane \\ University, 1060 Nishikawatsu, Matsue 690-8504, Japan \\ **Department of Applied Chemistry for Environment and Research Center for Coordination Molecule-based \\ Devices, School of Science and Technology, Kwansei Gakuin University, 2-1 Gakuen, Sanda 669-1337, \\ Japan
}

\begin{abstract}
The title compound of a lantern-type rhodium(II) dinuclear complex, cis- $\left[\mathrm{Rh}_{2}\left(3,5-\mathrm{Me}_{2}-\mathrm{pf}\right)_{2}\left(\mathrm{O}_{2} \mathrm{CCF}_{3}\right)_{2}\left(\mathrm{H}_{2} \mathrm{O}\right)_{2}\right] \cdot 0.5 \mathrm{C}_{6} \mathrm{H}_{14}$ (3,5-Me $-\mathrm{pf}^{-}=N, N^{\prime}$-bis(3,5-dimethylphenyl)formamidinate anion), was isolated and the crystal structure was determined by the single-crystal X-ray diffraction method at $90 \mathrm{~K}$. It crystallizes in the triclinic space group $P \overline{1}$ with $a=11.4725(16)$ $\AA, b=12.4679(17) \AA, \mathrm{c}=16.113(2) \AA, \alpha=77.391(2)^{\circ}, \beta=75.265(2)^{\circ}, \gamma=85.548(2)^{\circ}, V=2174.6(5) \AA^{3}, D_{\mathrm{x}}=1.548 \mathrm{~g} / \mathrm{cm}^{3}$, and $Z=2$. The $R 1[I>2 \sigma(I)]$ and $w R 2$ (all data) values are 0.0275 and 0.0625 , respectively, for all 9465 independent reflections. The cis-(2:2) arrangement of the 3,5- $\mathrm{Me}_{2}$-pf and trifluoroacetato ligands within the dinuclear core was confirmed, the axial sites of the dimer being occupied by the water molecules. The Rh-Rh distance is $2.4538(4) \AA$ and the axial Rh-O $\left(\mathrm{H}_{2} \mathrm{O}\right)$ distances are 2.3309(16) and 2.3196(16) $\mathrm{A}$.
\end{abstract}

(Received May 1, 2015; Accepted May 20, 2015; Published on web June 10, 2015)

There has been much interest directed to lantern-type diuclear metal complexes with direct metal-metal bonds due to their unique properties based on their metal-metal bonds. ${ }^{1,2}$ Formamidinate ions as well as carboxylate ions are known to work as a dinuclearting ligand to give a lantern-type dinuclear structure. ${ }^{1,2}$ Dinuclear complexes with the mixing of carboxylato and formamidinato bridges are intriguing, because the chemistry would be newly developed based on the different bridging groups within the dinuclear core. We have reported on the crystal structure rhodium(II) dinuclear complexes with two formamidinatao and two carboxylato bridging ligands in a cis$(2: 2)$ arrangement around the dinuclear core, cis- $\left[\mathrm{Rh}_{2}(4-\mathrm{Et}-\right.$ pf $\left.)_{2}\left(\mathrm{O}_{2} \mathrm{CCF}_{3}\right)_{2}\left(\mathrm{H}_{2} \mathrm{O}\right)(\mathrm{MeOH})\right] \quad$ (1) and cis-[Rh $\mathrm{Rh}_{2}(4-\mathrm{Et}-$ pf $\left.)_{2}\left(\mathrm{O}_{2} \mathrm{CCF}_{3}\right)_{2}(\mathrm{MeOH})_{2}\right]$ (2), where 4-Et-pf- = N, $N^{\prime}$-bis(4ethylphenyl)formamidinate anion. ${ }^{3,4}$ They have the same dinuclear structure with similar dimensions other than the

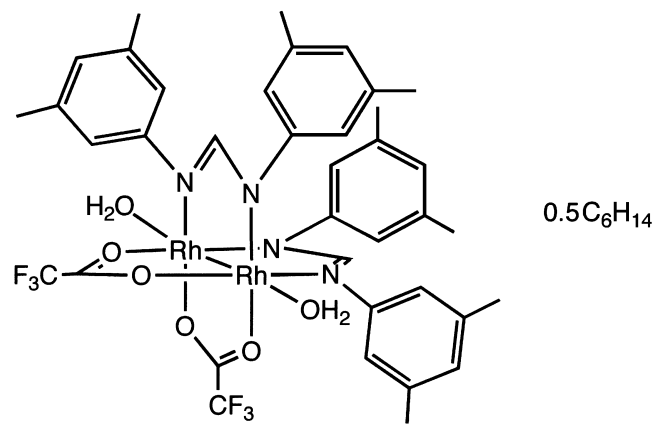

Fig. 1 Chemical structure of the title compound.

† To whom correspondence should be addressed. E-mail: handam@riko.shimane-u.ac.jp difference in the axial ligand between $\mathrm{H}_{2} \mathrm{O}$ and $\mathrm{MeOH}(\mathrm{Rh}-\mathrm{Rh}=$

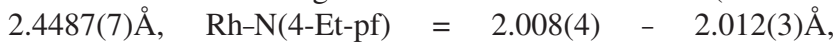
$\mathrm{Rh}-\mathrm{O}\left(\mathrm{O}_{2} \mathrm{CCF}_{3}\right)=2.078(3)-2.100(3) \AA, \mathrm{Rh}-\mathrm{O}\left(\mathrm{H}_{2} \mathrm{O}\right)=2.453(5)$ $\AA$, and $\mathrm{Rh}-\mathrm{O}(\mathrm{MeOH})=2.321(3) \AA$ for $1 ; \mathrm{Rh}-\mathrm{Rh}=2.4484(6) \AA$, Rh-N(4Et-pf) $=2.005(3)-2.016(3) \AA, \quad \mathrm{Rh}-\mathrm{O}\left(\mathrm{O}_{2} \mathrm{CCF}_{3}\right)=$ $2.079(2)-2.115(2) \AA$, and $\mathrm{Rh}-\mathrm{O}(\mathrm{MeOH})=2.314(2)$ and

Table 1 Crystal and experimental data

Chemical formula: $\mathrm{C}_{41} \mathrm{H}_{49} \mathrm{~F}_{6} \mathrm{~N}_{4} \mathrm{O}_{6} \mathrm{Rh}_{2}$

Formula weight $=1013.66$

$T=90 \mathrm{~K}$

Crystal system: triclinic $\quad$ Space group: $P \overline{1}$

$a=11.4725(16) \AA \quad \alpha=77.391(2)^{\circ}$

$b=12.4679(17) \AA \quad \beta=75.265(2)^{\circ}$

$c=16.113(2) \AA \quad \gamma=85.548(2)^{\circ}$

$V=2174.6(5) \AA^{3} \quad Z=2$

$D_{\mathrm{x}}=1.548 \mathrm{~g} / \mathrm{cm}^{3}$

Radiation: $\operatorname{Mo} K_{\alpha}(\lambda=0.71073 \AA)$

$\mu\left(\right.$ Mo $\left.K_{\alpha}\right)=0.834 \mathrm{~mm}^{-1} \quad F\left(\begin{array}{lll}0 & 0 & 0\end{array}\right)=1030$

Crystal size $=0.28 \times 0.20 \times 0.10 \mathrm{~mm}^{3}$

No. of reflections collected $=13170$

No. of independent reflections $=9465$

$\theta$ range for data collection: 1.67 to $28.36^{\circ}$

Data/Restraints/Parameters $=9465 / 0 / 540$

Goodness-of-fit on $F^{2}=0.920$

$R$ indices $[I>2 \sigma(I)]: R 1=0.0275, w R 2=0.0610$

$R$ indices (all data): $R 1=0.0376, w R 2=0.0625$

$(\Delta / \sigma)_{\max }=0.003$

$(\Delta \rho)_{\max }=0.941 \mathrm{e}^{-3} \quad(\Delta \rho)_{\min }=-0.465 \mathrm{e}^{-3}$

Measurement: Bruker Smart APEX CCD diffractometer

Program system: SHELXTL

Structure determination: Direct methods (SHELXS-97)

Refinement: full matrix least-squares (SHELXL-97)

CCDC deposition number: 1062091 
Table 2 Structural comparison of $c i s$ - $\left.\left[\mathrm{Rh}_{2}(\text { formamidinate })_{2} \text { (triflioroacetate }\right)_{2}\left(\mathrm{Lax}_{2}\right)_{2}\right]$ cores

\begin{tabular}{|c|c|c|c|}
\hline Compound & $\mathrm{Rh}-\mathrm{Rh}(\AA)$ & $\mathrm{Rh}-\mathrm{L}^{\mathrm{ax}}(\AA) /$ donor atom & Ref. \\
\hline cis- $\left[\mathrm{Rh}_{2}(4-\mathrm{Et}-\mathrm{pf})_{2}\left(\mathrm{O}_{2} \mathrm{CCF}_{3}\right)_{2}\left(\mathrm{H}_{2} \mathrm{O}\right)(\mathrm{MeOH})\right](\mathbf{1})$ & $2.4487(7)$ & $2.321(3) / \mathrm{O}_{\mathrm{MeOH}}, 2.454(5) / \mathrm{O}_{\mathrm{H}_{2} \mathrm{O}}$ & 3 \\
\hline$c i s-\left[\mathrm{Rh}_{2}(4-\mathrm{Et}-\mathrm{pf})_{2}\left(\mathrm{O}_{2} \mathrm{CCF}_{3}\right)_{2}(\mathrm{MeOH})_{2}\right](\mathbf{2})$ & $2.4484(6)$ & $2.314(2) / \mathrm{O}, 2.328(2) / \mathrm{O}$ & 4 \\
\hline cis- $\left[\mathrm{Rh}_{2}\left(3,5-\mathrm{Me}_{2}-\mathrm{pf}\right)_{2}\left(\mathrm{O}_{2} \mathrm{CCF}_{3}\right)_{2}\left(\mathrm{H}_{2} \mathrm{O}\right)_{2}\right] \cdot 0.5 \mathrm{C}_{6} \mathrm{H}_{14}(3)$ & $2.4538(5)$ & $2.3309(16) / \mathrm{O}, 2.3196(16) / \mathrm{O}$ & This work \\
\hline$c i s-\left[\mathrm{Rh}_{2}(4-\mathrm{Me}-\mathrm{pf})_{2}\left(\mathrm{O}_{2} \mathrm{CCF}_{3}\right)_{2}\left(\mathrm{H}_{2} \mathrm{O}\right)_{2}\right] \cdot 0.5 \mathrm{C}_{6} \mathrm{H}_{6}$ & $2.425(1)$ & $2.311(3) / O, 2.319(3) / O$ & 5 \\
\hline cis- $\left[\mathrm{Rh}_{2}(4-\mathrm{Me}-\mathrm{pf})_{2}\left(\mathrm{O}_{2} \mathrm{CCF}_{3}\right)_{2}(\mathrm{MeCN})_{2}\right]$ & $2.474(5)$ & $2.267(5) / \mathrm{N}, 2.265(5) / \mathrm{N}$ & 6 \\
\hline$\left[\mathrm{Rh}_{2}(4-\mathrm{Et}-\mathrm{pf})_{2}\left(\mathrm{O}_{2} \mathrm{CCF}_{3}\right)_{2}(\mathrm{pyz})\right]_{n} \cdot n$ (toluene $)$ & $2.4564(10)$ & $2.314(4) / \mathrm{N}, 2.286(4) / \mathrm{N}$ & 4 \\
\hline
\end{tabular}

2.328(2) $\AA$ for 2). ${ }^{3,4}$ Compared with lantern-type $\mathrm{Rh}_{2}$ dinuclear complexes with $N, N^{\prime}$-bis(4-alkylphenyl)formamidinato bridging ligands, ${ }^{5-7}$ the dinuclear complexes of the formamidinato ligands with alkyl groups at the 3 and 5 positions of the phenyl rings are relatively limited in number. ${ }^{1}$ Here, we report on the crystal structure of cis- $\left[\mathrm{Rh}_{2}\left(3,5-\mathrm{Me}_{2}-\mathrm{pf}\right)_{2}\left(\mathrm{O}_{2} \mathrm{CCF}_{3}\right)_{2}\left(\mathrm{H}_{2} \mathrm{O}\right)_{2}\right] \cdot 0.5 \mathrm{C}_{6} \mathrm{H}_{14}$ (3,5- $\mathrm{Me}_{2}-\mathrm{pf}^{-}=N, N^{\prime}$-bis(3,5-dimethylphenyl)formamidinate anion,) (3), of which the chemical structure is depicted in Fig. 1.

The synthetic procedure of $\left[\mathrm{Rh}_{2}\left(3,5-\mathrm{Me}_{2}-\mathrm{pf}\right)_{2}\left(\mathrm{O}_{2} \mathrm{CCF}_{3}\right)_{2}\right]$ is basically the same as those for $\left[\mathrm{Rh}_{2}(4-\mathrm{Et}-\mathrm{pf})_{2}\left(\mathrm{O}_{2} \mathrm{CCF}_{3}\right)_{2}\right]^{3,4}$ and $\left[\mathrm{Rh}_{2}(4-\mathrm{Me}-\mathrm{pf})_{2}\left(\mathrm{O}_{2} \mathrm{CCF}_{3}\right)_{2}\right] \quad$ (4-Me-pf $\quad=\quad N, N^{\prime}$-di- $p$ tolylformamidinate anion). ${ }^{5-7}$ Crystals suitable for X-ray crystal structure analysis were obtained by recrystallization from a THF solution containg hexane.

One of the blackish single crystals obtained for $\mathbf{3}$ was mounted on a Bruker CCD X-ray diffractometer (SMART APEX) using graphite-monochromated Mo- $K_{\alpha}$ radiation; a preliminary examination was made and data were collected. Crystal data and details concerning data collection are given in Table 1. The structure was solved by direct methods, and refined by full-matrix least-squares methods. The hydrogen atoms were inserted at their calculated positions and fixed there.

The crystal structure, drawn by ORTEP, is shown for $\mathbf{3}$ in Fig. 2. The selected bond distances and angles are given in Table S1. It is clearly shown that bridging ligands, 3,5- $\mathrm{Me}_{2}-\mathrm{pf}^{-}$and $\mathrm{CF}_{3} \mathrm{CO}_{2}^{-}$, adopt the cis-(2:2) arrangement around the $\mathrm{Rh}_{2}$ lantern-type dinuclear core. The packing diagram (Fig. S1) shows that hexane molecules exist as the crystal solvent other than the the $\mathrm{Rh}_{2}$ dinuclear units with axial water molecules; there is no contact to be mentioned between the crystal solvent hexane and the $\mathrm{Rh}_{2}$ dinuclear unit. The $\mathrm{Rh}(1)-\mathrm{Rh}(2)$ distance is $2.4538(4) \AA$. This short distance is indicative of the existence of a direct $\mathrm{Rh}-\mathrm{Rh}$ bond within the dinuclear core. ${ }^{1}$ The axial water molecules coordinate to the dinuclear core with the distances of 2.3309(16) (for $\mathrm{Rh}(1)-\mathrm{O}(5)$ ) and 2.3196(16) $\AA$ (for $\mathrm{Rh}(2)-\mathrm{O}(6)$ ). The axial distances are similar to those of $\left[\mathrm{Rh}_{2}(4-\mathrm{Me}-\right.$ pf $\left.)_{2}\left(\mathrm{O}_{2} \mathrm{CCF}_{3}\right)_{2}\left(\mathrm{H}_{2} \mathrm{O}\right)_{2}\right] \cdot 0.5 \mathrm{C}_{6} \mathrm{H}_{6}(2.311(3)$ and $2.319(3) \AA){ }^{5}$ The $\mathrm{Rh}-\mathrm{Rh}$ and $\mathrm{Rh}-\mathrm{L}^{\mathrm{ax}}\left(\mathrm{L}^{\mathrm{ax}}=\right.$ axial ligand) bond distances are summarized in Table 2 for the lantern-type rhodium(II) dinuclear cores with the cis-(2:2) arrangement of formadinate and trifluoroacetate bridging anions. The $\mathrm{Rh}-\mathrm{Rh}$ bond lengths, $\left(2.474(5) \AA\right.$ for $\quad c i s-\left[\mathrm{Rh}_{2}(4-\mathrm{Me}-\mathrm{pf})_{2}\left(\mathrm{O}_{2} \mathrm{CCF}_{3}\right)_{2}(\mathrm{MeCN})_{2}\right]$ and $2.4564(10)$ for $\left[\mathrm{Rh}_{2}(4-\mathrm{Et}-\mathrm{pf})_{2}\left(\mathrm{O}_{2} \mathrm{CCF}_{3}\right)_{2}(\mathrm{pyz})\right]_{n} \cdot n$ (toluene)), of the dinuclear complexes axially coordinated by nitrogen atoms are rather longer than those $(2.4487(7) \AA$ for $1,2.4484(6) \AA$ for

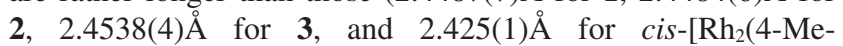
pf $\left.\left.)_{2}\left(\mathrm{O}_{2} \mathrm{CCF}_{3}\right)_{2}\left(\mathrm{H}_{2} \mathrm{O}\right)_{2}\right] \cdot 0.5 \mathrm{C}_{6} \mathrm{H}_{6}\right)$ of the dinuclear cores axially coordinated by oxygen atoms. This could come from the stronger donating nature of nitrogen atoms $(\mathrm{MeCN}$ and pyz (pyrazine)) compared with that of oxygen atoms $(\mathrm{MeOH}$ and $\mathrm{H}_{2} \mathrm{O}$ ). ${ }^{3-6}$ There seems to be no important effect on the $\mathrm{Rh}-\mathrm{Rh}$ bond length due to the difference in the substituted alkyl groups (Me and Et), their numbers, and positions on the phenyl rings of the formamidinato ligands.

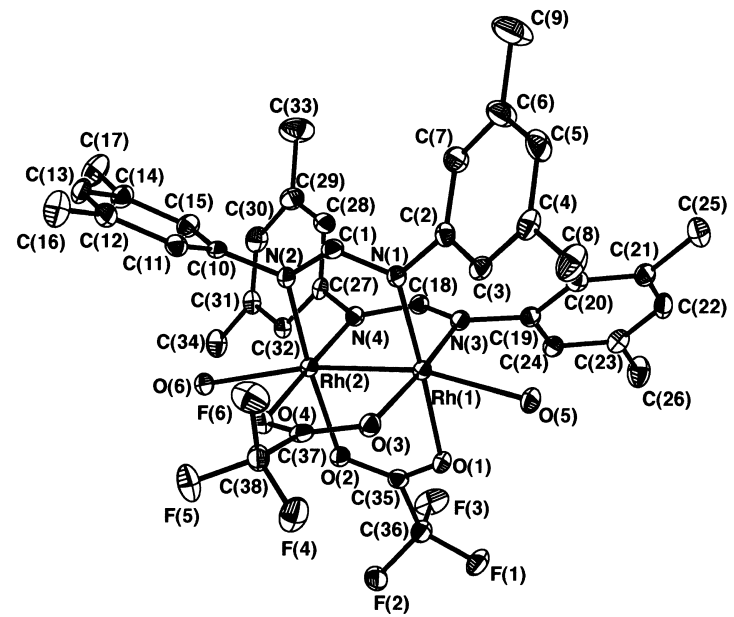

Fig. 2 ORTEP view of the title compound, 3. Hydrogen atoms are omitted for clarity. Thermal ellipsoids are shown at the $50 \%$ probability level.

\section{Acknowledgements}

The present work was partially supported by the MEXTSupported Program for the Strategic Research Foundation at Private Universities and Grants-in-Aid for Scientific Research No. 26410080 from the Ministry of Education, Culture, Sports, Science and Technology (MEXT).

\section{References}

1. F. A. Cotton, C. A. Murillo, and R. A. Walton, "Multiple Bonds Between Metal Atoms", 3rd ed., Springer Science and Business Media, New York, 2005.

2. M. Mikuriya, D. Yoshioka, and M. Handa, Coord. Chem. Rev., 2006, 250, 2194.

3. M. Handa, R. Inoue, A. Inoue, T. Nakai, T. Ikeue, D. Yoshioka, and M. Mikuriya, X-ray Struct. Anal. Online, 2012, 28, 53.

4. M. Handa, T. Ikeue, A. Sanaka, T. Nakai, H. Tanaka, D. Yoshioka, and M. Mikuriya, in "New Trends in Coordination, Bioinorganic, and Applied Inorganic Chemistry," ed. by M. Melnik, P. Segla, and M. Tatarko, Slovak University of Technology Press, Bratislava, 2011, p. 133.

5. P. Piraino, G. Bruno, G. Tresoldi, S. L. Schiavo, F. Laschi, and P. Zanello, Inorg. Chem., 1987, 26, 91.

6. K. V. Catalan, J. S. Hess, M. M. Maloney, D. J. Mindiola, D. L. Ward, and K. R. Dunbar, Inorg. Chem., 1999, 38, 3904.

7. P. Piraino, G. Tresoldi, and F. Faraone, J. Organomet. Chem., 1982, 224, 305. 